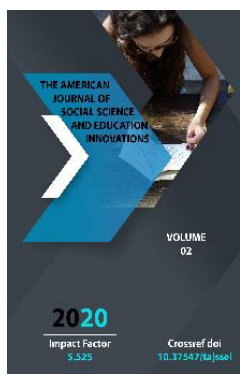

\title{
The History Of The Early Medieval Sugd Court (Based On The Mug Mountain Archive)
}

\author{
Khalikulov Azizbek Yorqulovich \\ Researcher At Samarkand State University, Uzbekistan
}

Copyright: Original content from this work may be used under the terms of the creative commons attributes 4.0 licence.

\section{ABSTRACT}

The article provides information on the state court and economic relations in Sughd in the early Middle Ages, the procedure for conducting and processing trade documents, certificates and receipts. Opinions were analyzed on the basis of Mug Mountain documents, ie correspondence between rulers and courtiers, reports of certificates of economic income and expenditure, archival documents on receipts.

\section{KEYWORDS}

Early Middle Ages, Kingdom of Sughd, Mug archive, documentary tradition, receipts, seals, economic acts.

\section{INTRODUCTION}

Documents of Mug Mountain include correspondence of Devashtich and his entourage and government officials, economic reports, registers of food and money spent, taxes and expenditures, certificates and receipts of income and expenditure of agricultural, livestock and handicraft products summed up. Among the documents, the decrees related to the name of the governor of Panch Devashtich, instructions to various persons are an important source in the analysis of the principles of public administration. 
Mug documents provide interesting information about the persons who held key positions in the economy and management of the Palace of the Panch Khokimiyat in the VIIVIII centuries. For example, a man named Utt, who worked in the aforementioned framandar position, had a very wide range of activities. This person was a representative of the Turkish people by name and ran the palace economy. According to documents A-1, A-2, A-3, A-6, A-16, $\mathrm{A}-18, \mathrm{~B}-11, \mathrm{~B}-13, \mathrm{~B}-15, \mathrm{~B}-18, \mathrm{~B}-19$, Utt was responsible to the task of controlling the distribution of products coming to the center from all agricultural sectors and distributed from the center throughout the region is assigned to the Panj khokimiyat.[8]

Documents numbered A-2, A-3, A-16, written in the name of Framandar, are executed mainly in the form of letters. In fact, these documents were decrees in terms of their function. At the same time, they considered it a report document on the performance of the assigned task: "and keep this letter (letter) as a document of acquittal", ie the document states that the rest of May should be sealed and this copy of the order should be kept in place of receipt. [2] A similar situation is found in $\mathrm{V}-3, \mathrm{~A}-$ $10, A-7$ and other documents, and this group is called "receipts" in water science. In the tradition of documentation, it was strictly customary to mark this or that document, especially the date, year, month and day of the receipts.The date is indicated at the beginning or end of the document and is written by the first or third person. Sometimes at the end of the document "This letter was prepared in duplicate. Keep one of them for your report". In the text, the word is defined by the Sogdian term "patsahv", which means "the answer to be given later". In particular, the date of the A16 document is the date of the relative era, where at the end of the text "It is the second year of the kingdom of Devashtich. Oyixvareznich, kuni-naxran ruch. This order was sealed by King Devashtich and written in a second copy by royal decree. Mug documents state that each king kept an account of the year from the time he came to the throne. The lunar and day calendar, on the other hand, continued the Zoroastrian calendar system. [2]

Prior to the Arab conquest, Sughd had a unique annual calendar. In Sughd, for example, in Iranian and Turkish chronicles in general, the reckoning of the year began with the accession of a certain ruler or king to the throne. We find the same situation in the Sogdian-Buddhist texts. Kings or rulers ascended the throne at the beginning of the new year during the days of Navruz, that is, from late March to mid-April, unless there was an emergency. This in turn also served for a certain accuracy in the annual accounts. [5]

Among the Mug archives is a group of covering the 10th year of the Tarhun era of the Sogdian king (Nov.3, Nov.4), as well as 14 years (708722) related to the rule of Devashtich. [9] The beginning and ending parts of the documents are traditionally used, especially in the letters addressed to Devashtich, with the lavish sentences: "Mr. Ruler, our great support." In some cases, brief application forms are found in documents drawn up on behalf of senior officials. Such a clear accounting tradition in documentation demonstrates the organizational resilience of the management judiciary. The fact that the documents are considered accountable also points to the perfection of early medieval legal relations.

Actually, most of the documents in the decree are copies of Governor Devashtich's letters. Their originals were certified by Devashtich and 
sometimes fortified with a clay seal. A bulla (a seal imprinted on the mud, that is, a document wrapped in a tube wrapped in a drawing, covered with mud, and stamped on it) arrived with the seal of the king. It contains an image of a mountain bull and a Sogdian inscription stating that "this document is reliable" ("symbol of trust", "original"). [1] The document, made up in two or three copies, is written in one copy for the person receiving the product, the person delivering it and the framer, and is called "equal", "same" in terms of content.Receipts, instructions, and command documents show that in early medieval Sogdia, there were specific diplomatic relations in the management of the economy and in political dialogue with other rulers, especially during the Arab conquest.

There is also sufficient information about the officials in the Punch Palace who were subordinate to Devashtich and directly to the framers. For example, the position of head of the state court is dapirpat. The term consists of two parts: dapir- "to write, to write", pat"chief", meaning the chief of secretaries. Document A-5 provides information on the salary paid to the holder of this position. [2]

Document A- 6 mentions the position of the propeller hire. He was described in the press as a "document writer." But it was not just the position of the compiler of the document, but a court headed by a secretary-dapirpat. Parvonak Kirok, on the other hand, dealt with a group of documents related to the performance of awards and charitable donations of kings or governors in special cases. [2]

The Devashtich Palace had a high level of court records and records. The saved documents reflect a well-crafted office correspondence style. The secretaries who prepared the unilateral and bilateral documents had a high level of literacy and writing skills. Ethnically, they were mainly Sogdians and Turks, and both languages were spoken in the Devashtich Palace. This is evidenced by the fact that the document, written in the ancient Turkic script number B-13, is in the Mug archives. [9]

Two Arabic letters related to the name of Devashtich also arrived. But these texts are not sufficient to conclude that the Sogdians knew Arabic. Presumably, at the request of the period of the Arab conquest, Devashtich used the services of an Arabic-speaking secretary in the palace. Documents $A-18, A-1, A-3, A-16, A-13$, which belong to the series of decrees, are the orders sent by Devashtich in the form of a letter to the framer Utt. It is clear from the content of the texts that the distribution of food throughout the country was carried out by the framandar by order of Devashtich. These documents, sent in the form of a letter, indicate that the framer's workplace (warehouse) was far from Devashtich's palace. Framandar worked mainly with products necessary for domestic needs, including wheat products and may (drink). In addition, meat and other products are partially mentioned in the documents in his possession. V.A. Livshits expressed his opinion in the study of the personality of Framandar Utt. According to him, "Utt" means "fire" in this Turkish language. That is why he interprets framandar as a representative of the Turkic people. But it is not possible to see a single person in the image of the framer Utt with Ottakin mentioned in the Nov.3,4 document. [8] Undoubtedly the framer was one of the officials of the Utt Devashtich Palace. He controlled the inflow of agricultural products, military weapons and handicrafts into the 
palace treasury from the territories under the rule of Panjikent, as well as from the villages of Upper Zrafshan (Fatmev, Iskodar, Qum, Madm, etc.). Document B-11 contains records of grain and livestock products from these villages. Under the direction of Framandar Devashtich, he controlled the supply of food from the villages to some individuals (documents B-13, B15). He also distributed food products (eg grain, A-18, A-2 documents) to collective farmers sent to other villages to work. Documents Nov.1 and B-1 refer to the distribution of firearms by a framer to a number of individuals. In addition, Devashtich himself personally oversaw the arrival and distribution of food and weapons.

Document A-5 (report) lists the amount of money given to the people of Devashtich Palace, all of them by name. But the name of the commander Utt never appears there. [8] Interestingly, the framer Utt spent most of his time outside of Panjikent. An example of this is the letters about Devashtich's instructions. Framandar had settlements outside the city, one of which was the village of Filmandar, located in the valley of the Maghion River. Perhaps that is why the village was named Filmandar-farmandar.

The document number $\mathrm{A}-18$ is $10 \times 8.5 \mathrm{~cm}$. It is a Sogdian document of 10-12 lines, written on a thin light gray paper, in which Devashtich expresses his displeasure with the foodproducing framer Utt for his unfulfilled order. The Devashtich decree stated that the framandar did not bow down, and that the people of Zrunb should not be indifferent to their condition and should give 200 caps of flour so that they would not suffer from hunger. At the end of the document, the phrase "and do not procrastinate" was used.
The text A-2 is a Sughd document measuring $12 \times 11 \mathrm{~cm}$, which is a letter from Devashtich to the framer Utt. In the same document, Devashtich said that 300 bags of flour should be given to the hungry population of Aski Razr and that this work should not be delayed. The leather A-3 document, $14.5 \times 10.7 \mathrm{~cm}$, also contains Devashtich's order to give 200 bags of flour to Khufarn and Khutachan. Document A16 , written on $12-12.5 \times 17 \mathrm{~cm}$ paper, states that Devashtich's economic officer, Framandar Utt, should give Litfir to May as soon as he receives the letter. Interestingly, to emphasize that the wine should be of pure quality, Devashtich referred to it as the 'maid's drinking field'. The document was written in duplicate by order of Devashtich, stating that the remainder of the order should be sealed and that a copy of the order should be kept in place of the receipt. The opening and closing parts of the documents are traditionally used, especially in the letters addressed to Devashtich, with the lavish sentences: "Mr. Ruler, to our great support." In some cases, brief application forms are found in documents drawn up on behalf of senior officials. Among the documents of the mug is the term abvozipat the position of the person in charge of the production of leather, fur, their collection from the population, their transfer to the treasury and storage. The name of this official is also known - Vgashmarik. He was entrusted with the task of preparing livestock products, in particular leather ("pustak", "pustak") in the Punch administration. Hence, the economic sectors were clearly distributed in Panch Province.

Another high-ranking post was called bazcrom. The name of the person performing this function is not specified. Document A-10 refers to the position of bazkrom in connection with 
the payment for the use of the bridge and states that it is necessary to pay 150 drachms (silver currency). This document can be considered as a payment notice. This letter shows the high level of state accountability, showing the property relations and the legal aspects of their use. As noted above, the territorial divisions within the khokimiyat were sometimes governed by persons in hvabu positions. But it should not be forgotten that the governor of Panch is also called hvabu. This case suggests that territorial governments may sometimes have a status similar to internal autonomy or come up with such a claim. We can see this in Devashtich's letters to Afarun, the governor of Khahsar. There is no clear idea of the social status of the katiabshivs, the 'village great' found in the documents. But on the basis of the kati part of the word, it may be meant a clan (clan-clan community) that is part of the village.

One of the important aspects of the B-4 "mill lease" document is that the document is sealed. The seal is represented in the text by the phrase "gyromitr." The word 'gira' means 'mud'. "Mitr" is known among the ancient peoples of Central Asia as a goddess of peace and trust (epithets of the god Mitra). [1] That is why, Uttakin is also making commitments to Cher and his children. Document No. 4 (marriage contract) mentions Mitra's name: "In your presence and in Mitra's testimony." Researcher $M$. Ishakov considers the etymology of the word seal, ie the history of its origin, to be connected with the name of the god Mitra. The seal is printed on the top seam when the document is wrapped in a tube. There are also traces of writing on his traces, which were found to be Sogdian. The presence of a seal in the document also serves as a valuable material for Sughd seals-sphragistics.
It is also noted in the texts of documents A-13 and $\mathrm{A}-16$ that the documents were certified with a mud seal. [2] Documents containing Devashtich's orders, such as A-2, A-3, contain traces of his personal seal-ring seal. The Devashtich seal had the image of a zebu (a wild type of cattle).

At the end of the document in the archives it is noted that "this letter was sealed by Devashtich in the second year of the kingdom of Devashtich, in the month of Khvariznich, on the day of Nagran Ruch, and a (second) copy was prepared by his (the king's) order." A number of documents among the Mughal mountain manuscripts point to the economic hardships caused by the Arab conquest, the economic difficulties. They often address the issue of providing people with grain products. It is noteworthy that the king himself was personally engaged in this important work. As noted above, in one of the documents, Devashtich ordered the framer, Utt, to give 300 cups of grain to the hungry people of AskiRazr without hesitation.

The A-18 digital document is similar in some respects, and in some respects it differs from the usual official tone. It is clear from the content of this letter that Devashtich was forced to repeat the order to give grain to the people of Zrunb village for the second time. So the framer asked Utt, "You don't do what I tell you to do, but you do what I tell you not to do?" is making a mockery of the tribe. [8] Letters addressed to Afarun, such as B-14 and B-16, are methodologically almost indistinguishable from letters addressed to the supreme ruler Devashtich. [4] This indicates that the Munshaat style has a long tradition in the Sughd court. Structurally, the abovementioned Mughal Mountain Sughd documents reflect thehigh level of strict 
documentary tradition in the early Middle Ages in the system of state litigation, documentation of economic relations, management in Sughd.

\section{REFERENCES}

1. Ishakov M.M. Sogdiana at the crossroads of history. Tashkent - Science, 1990.

2. Ishakov M.M. Letters from the Forgotten Kingdom. Tashkent - Fan, 1992.

3. Livshitsa V.A. // Sogdian documents with mountain Mug. Reading, translation, commentary. Issue II. Moscow. "Izdatelstvo Vostochnoy literatury". 1962.

4. Mansurov O.N. Issues of source studies of Sughd written monuments Tashkent 2003.

5. Otaxo'jaev A. Turkish governor of Sughd.

6. Smirnova O. I. Map of Zeravshan on the documents. M., 1960 («XXV Mezhdunarodnyy congress vostokovedov. Dokladydelegatsii SSSR»).

7. SmirnovaO.I. OcherkiizistoriiSogda. - M: Nauka, 1970.

8. Sogdian documents with the mountain Mug. Vypusk II ... -P. 72.

9. Sogdian documents with the mountain Mug. Vypusk III... -P.57. 